Gonzalez-Quevedo, C., A. Pabón, and H. F. Rivera-Gutierrez. 2016. Prevalence of haemosporidians in a Neotropical endemic bird area. Avian Conservation and Ecology 11(1):7. http://dx.doi.org/10.5751/ACE-00834-110107

Copyright (C) 2016 by the author(s). Published here under license by the Resilience Alliance.

Short Communication

\title{
Prevalence of haemosporidians in a Neotropical endemic bird area
}

Catalina Gonzalez-Quevedo ${ }^{1}$, Adriana Pabón ${ }^{2}$ and Hector Fabio Rivera-Gutierrez ${ }^{1}$

${ }^{1}$ Grupo Ecología y Evolución de Vertebrados, Instituto de Biología, Facultad de Ciencias Exactas y Naturales, Universidad de Antioquia, Medellin, Colombia, ${ }^{2}$ Grupo Malaria, Facultad de Medicina, Universidad de Antioquia, Medellín, Colombia

\begin{abstract}
Haemosporidians are vector-transmitted intracellular parasites that occur in many bird species worldwide and may have important implications for wild bird populations. Surveys of haemosporidians have traditionally focused on Europe and North America, and only recently have they been carried out in the Neotropics, where the prevalence and impacts of the disease have been less studied and are not well understood. In this study we carried out a survey in the endemic bird area of the Sierra Nevada de Santa Marta (SNSM), an isolated coastal massif in northern Colombia that contains a large number of biomes and that is experiencing high rates of habitat loss. We sampled birds from 25 species at 2 different altitudes (1640 and $2100 \mathrm{~m}$ asl) and determined avian haemosporidian infection by polymerase chain reaction and sequencing a portion of the cytochrome $b$ (cyt $b$ ) gene of the parasite. From the sampled birds, 32.1\% were infected by at least 1 of 12 unique cyt $b$ lineages of haemosporidian genera: Plasmodium, Leucocytozoon, Haemoproteus, and subgenus Parahaemoproteus. We found a higher prevalence of avian haemosporidians at low altitudes (1640 m asl). All endemic bird species we sampled had at least one individual infected with avian haemosporidians. We also found evidence of higher overall prevalence among endemic rather than nonendemic birds, suggesting higher susceptibility in endemic birds. Overall, our findings suggest a high haemosporidian species richness in the bird community of the SNSM. Considering the rate of habitat loss that this area is experiencing, it is important to understand how avian haemosporidians affect bird populations; furthermore, more exhaustive sampling is required to fully comprehend the extent of avian haemosporidian infection in the area.
\end{abstract}

\section{Prévalence d'hémosporidies dans une région néotropicale d'endémisme aviaire}

RÉSUMÉ. Les hémosporidies, parasites intracellulaires transmis par vecteur, se trouvent dans de nombreuses espèces d'oiseaux partout dans le monde et pourraient avoir d'importantes répercussions dans les populations d'oiseaux sauvages. Traditionnellement, la détection de la présence d'hémosporidies a surtout été réalisée en Europe et en Amérique du Nord, et c'est seulement récemment qu'elle a été faite en région néotropicale, où la prévalence et les impacts de la maladie ont été moins étudiés et sont mal compris. Dans la présente étude, nous avons procédé à la détection dans la région d'endémisme aviaire de la Sierra Nevada de Santa Marta (SNSM), un massif côtier isolé dans le nord de la Colombie qui comporte un grand nombre de biomes et subit un taux élevé de perte d'habitat. Nous avons échantillonné des oiseaux appartenant à 25 espèces à deux altitudes différentes (1 640 et $2100 \mathrm{~m}$ asl) et avons déterminé l'infection par les hémosporidies à l'aide de la réaction en chaîne de la polymérase et du séquençage d'une portion du gène cytochrome $b$ (cyt b) du parasite. Parmi les oiseaux échantillonnés, 32,1\% étaient infectés par au moins 1 des 12 souches du cyt b uniques aux genres d'hémosporidies Plasmodium, Leucocytozoon, Haemoproteus, et au sous-genre Parahaemoproteus. Nous avons détecté une plus grande prévalence d'hémosporidies aviaires à faible altitude (1640 $\mathrm{m}$ asl). Toutes les espèces d'oiseaux endémiques que nous avons échantillonnées présentaient au moins un individu infecté par des hémosporidies aviaires. Nous avons aussi obtenu des indices d'une plus grande prévalence en général chez les espèces endémiques par comparaison aux espèces non endémiques, ce qui laisse entendre qu'une plus grande vulnérabilité existerait chez les oiseaux endémiques. Dans l'ensemble, nos résultats indiquent qu'une richesse élevée d'espèces d'hémosporidies s'observe dans la communauté aviaire de la SNSM. Considérant le taux de perte d'habitat que cette région subit, il est important de comprendre comment les hémosporidies aviaires affectent les populations d'oiseaux; en outre, un échantillonnage plus intensif est nécessaire si nous voulons comprendre pleinement l'étendue des infections par hémosporidies aviaires dans la région.

Key Words: avian malaria; endemic bird area; haemosporidian; Sierra Nevada de Santa Marta

\section{INTRODUCTION}

Understanding the threats of infectious disease in the wild is a central issue for wildlife conservation (Scott 1988, Thompson et al. 2010). Such understanding is becoming more important as climate change-induced habitat changes are quickly affecting the distribution of parasites and hosts (Garamszegi 2011). In the last few decades an increase in the prevalence of some infectious diseases in wild populations has been documented (Daszak et al. 2000, Dobson and Foufopoulos 2001, Hatcher et al. 2012) and these can have a significant impact on wild populations (Scott 1988). 
Avian malaria (Plasmodium sp.) and other haemosporidians (Leucocytozoon, Haemoproteus, and subgenus Parahaemoproteus spp.) are vector-transmitted intracellular blood parasites (hereafter haemosporidians) that occur on every continent apart from Antarctica (Valkiūnas 2004). These parasites occur in many bird species, but are mainly found infecting passerines (Valkiūnas 2004). Traditionally, the detection and classification of avian haemosporidians have been done using light microscopy. However, the advent of molecular polymerase chain reaction (PCR)-based detection methods has revealed many insights about parasite genetic diversity (Hellgren et al. 2004, Waldenström et al. 2004) and has allowed the detection of over 1300 unique avian haemosporidian lineages (MalAvi database, Bensch et al. 2009). These haemosporidian lineages vary in the degree of avian host specificity (Ricklefs et al. 2004, Fallon et al. 2005), with some lineages restricted to individual host species, whereas others have a wide range of hosts (Hellgren et al. 2009). Recent evidence suggests that Plasmodium lineages are more generalist, whereas specialist associations are more common in Haemoproteus (Bensch et al. 2000, Beadell et al. 2009). No studies have been done on the degree of host specialization of Leucocytozoon lineages.

The different genera of haemosporidians differ in some features of their life cycle, but clinical aspects of infection in vertebrate hosts are very similar (Van Riper et al. 1994). Once infected, birds undergo an acute phase where parasitaemia (number of individual parasites) increases to a peak approximately $6-12$ days after infection (Van Riper et al. 1994). After the acute phase, surviving birds may completely clear an infection or alternatively infection may become chronic with very low levels of parasitaemia (Van Riper et al. 1994). Infection induces an antibody and cellmediated immune response in hosts (Atkinson et al. 2001), and when birds are re-exposed to the same haemosporidian they may quickly mount an effective immune response to control the infection (Cellier-Holzem et al. 2010).

Apart from the role of host immune response in the risk of haemosporidian infection, the environment also modulates infection risk. Avian haemosporidian infection has been associated with environmental variables such as temperature, altitude, and precipitation (reviewed in Sehgal 2015). This is due to the effects of these variables on parasite and vector development (LaPointe et al. 2010, 2012). An elevation limit of avian haemosporidians was documented in Hawaii at approximately $1500 \mathrm{~m}$ during the 1970s (van Riper et al. 1986); as a consequence, susceptible hosts have suffered range restrictions, and can only be found above this altitude. However, there have been recent reports of avian haemosporidians at much higher altitudes in this island (Freed et al. 2005), and in continental areas (Rodríguez et al. 2009), a phenomenon probably related with global warming (Garamszegi 2011) that could have grave implications for birds with restricted distributions.

The recent methodological advances in the detection of avian haemosporidian infection have led to an increase in the number of published surveys across the world (reviewed in Clark et al. 2014). Some biogeographical patterns of haemosporidian distribution have been inferred. For example, continental avian diversity hotspots tend to have higher avian haemosporidian species richness estimates compared to non-hotspots. Another interesting pattern is that continental South America harbours the largest number of lineages of both Plasmodium and Haemoproteus (Clark et al. 2014). However, much of the research that has been done is restricted to European and North American passeriform communities, and only a few sites have been sampled in continental Neotropics (Lacorte et al. 2013, Clark et al. 2014, González et al. 2015, Marzal et al. 2015). Thus, species richness for continental Neotropics is likely to be underestimated.

Introduced haemosporidians in isolated islands may pose a threat to naïve endemic birds that have not evolved ways to counteract the infection. Such is the case of some Hawaiian birds that suffered large population declines after the haemosporidian vectors were accidentally introduced to the islands (Warner 1968, van Riper et al. 1986). Negative impacts caused by haemosporidian infection include death (Atkinson et al. 2000, Sol et al. 2003), reduced body condition (Merino et al. 2000, Calero-Riestra and García 2016), increased risk of predation (Møller and Nielsen 2007), lower reproductive success (Merino et al. 2000, Marzal et al. 2005), and reduced lifespan (Asghar et al. 2015). The Neotropical region has a large number of endemic bird areas (42) and avian haemosporidians may pose a greater threat to continental endemic birds because they have restricted distributions and populations cannot avoid infection. The study of avian haemosporidians in areas of high bird endemism has been restricted to islands and little attention has been paid to continental areas of high bird endemism.

The aim of this study was to conduct a preliminary survey of the prevalence of avian haemosporidian parasites in the endemic bird area of the Sierra Nevada de Santa Marta in northern Colombia, home to a variety of biomes and one of the world's most important continental avian centers of endemism (Cracraft 1985, Carbono and Lozano-Contreras 1997). Only 15\% of the original forest cover in the Sierra Nevada remains (Strewe and Navarro 2004), and despite having a large proportion within national and private protected areas, it is still experiencing high rates of habitat loss. In addition to habitat-related threats, the local avifauna could also be exposed to infectious diseases, which could exacerbate the effects of habitat reduction on the local populations.

\section{METHODS}

\section{Study area}

The Sierra Nevada de Santa Marta (SNSM) is an isolated mountain range located in northern Colombia $42 \mathrm{~km}$ off the Atlantic coast (Fig. 1). It reaches an altitude of $5775 \mathrm{~m}$ above sea level (asl) and encompasses $17,000 \mathrm{~km}^{2}$ in the departments of Magdalena, Cesar, and La Guajira. The climate in the SNSM is characterized by temperatures that vary between $0^{\circ} \mathrm{C}$ and $28^{\circ} \mathrm{C}$ and mean annual rainfall of approximately $1500 \mathrm{~mm}$ at elevations of $500 \mathrm{~m}$. Rainfall regime is bimodal with two peaks in September - December and May_June and two dry periods in JanuaryApril and July_-August (Instituto Geográfico Agustín Codazzi [IGAC] 1993). The SNSM is characterized by a large variety of habitats resulting from the altitudinal range and its location; the area presents a mosaic of different biomes including mangroves, semideserts, tropical dry forests, tropical wet forests, montane forests, and páramos (Strewe and Navarro 2004). Because of its isolation and variety of habitats the SNSM is constituted as an important Endemic Bird Area (Stattersfield et al. 1998) with 18 
endemic species and 55 endemic subspecies. Our study site is located in the San Lorenzo ridge in the northwest slope of the SNSM in the department of Magdalena where two collection points were chosen, one at 1640 and another at 2100 meters asl (Fig. 1).

Fig. 1. Location of the sampling sites in the San Lorenzo ridge within the Sierra Nevada de Santa Marta in northern Colombia.

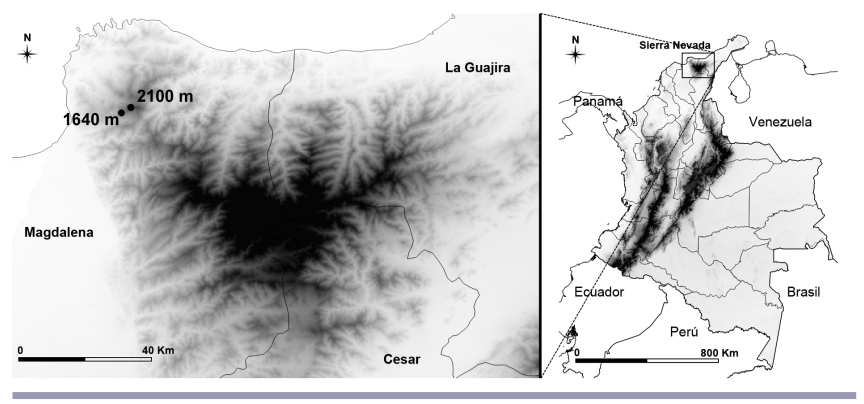

\section{Sampling and molecular procedures}

Birds were captured in February 2014 and June 2015 using mist nets (12-m-long $\times 3-\mathrm{m}$-high). Each captured bird was marked for subsequent identification when recaptured by clipping the tail feathers. A small ( 20 $\mu$ l) blood sample was obtained by brachial venipuncture using a sterile hypodermic needle. Blood was collected in Queen's lysis buffer (Seutin et al. 1991) in $1.5 \mathrm{ml}$ microcentrifuge tubes at room temperature.

Genomic DNA was extracted from blood using a salt extraction method (Richardson et al. 2001). Quality of the DNA was assessed by PCR of a fragment of approximately $950 \mathrm{bp}$ of the avian mitochondrial gene ND4 using primers ND4 and LEU (Arèvalo et al. 1994) and PCR conditions previously described (McGuire et al. 2007). Only DNA samples that successfully amplified the avian mitochondrial marker were used in the haemosporidian screening. Haemosporidian infection was screened using a nested PCR method that amplifies a section of the cytochrome $b$ gene of the haemosporidian genome. PCR was performed in $10 \mu$ l volumes containing $~ 30 \mathrm{ng}$ of genomic DNA (universal PCR) or amplicon (nested PCRs), $2 \mathrm{mM}$ each dNTP, $0.5 \mu \mathrm{M}$ each primer, $2 \mathrm{mM} \mathrm{MgCl}, 1 \mathrm{X}$ PCR buffer, and 0.03 units of Taq polymerase (Thermo Scientific). Universal PCR was done using primers HAEMNF1 and HAEMNR3 (Hellgren et al. 2004); the thermal profile started with $3 \mathrm{~min}$ at $96^{\circ} \mathrm{C}$ followed by 20 cycles of $96^{\circ} \mathrm{C}$ for $20 \mathrm{sec}, 50^{\circ} \mathrm{C}$ for $30 \mathrm{sec}$, and $72^{\circ} \mathrm{C}$ for $45 \mathrm{sec}$, and ended with an extension step at $72^{\circ} \mathrm{C}$ for $10 \mathrm{~min}$. Nested PCR was done with primers HAEMF and HAEMR2 for Plasmodium and Haemoproteus (Bensch et al. 2000) and HAEMFL and HAEMR2L for Leucocytozoon (Hellgren et al. 2004). Thermal profiles started with $3 \mathrm{~min}$ at $96^{\circ} \mathrm{C}$, followed by 40 cycles of $96^{\circ}$ $\mathrm{C}$ for $30 \mathrm{sec}, 55^{\circ} \mathrm{C}$ (for Plasmodium/Haemoproteus) or $57^{\circ} \mathrm{C}$ (for Leucocytozoon) for $45 \mathrm{sec}$, and $72^{\circ} \mathrm{C}$ for $45 \mathrm{sec}$, and ended with a final extension at $72^{\circ} \mathrm{C}$ for $10 \mathrm{~min}$. PCR products were visualized in $2 \%$ agarose gels stained with GelRed (Biotium). We routinely used negative controls. All samples were screened at least twice and only samples that amplified twice were considered to be infections.
PCR products were sequenced in Macrogen Inc. using the BigDye reaction (Thermo Scientific) and running products on an automated sequencer. Sequences were visually checked and edited in Bioedit 7.0.9 (Hall 1999), and aligned to sequences from the National Center for Biotechnology Information GenBank database and the MalAvi database for avian malaria (Bensch et al. 2009).

\section{Analyses}

To determine the relationship between the avian haemosporidian parasite lineages identified we constructed maximum likelihood trees with the unique sequences using 1000 bootstrap replications and the general time reversible substitution model using MEGA 6 (Tamura et al. 2013). The tree was rooted using a published sequence of Babesia gibsoni (GenBank accession number AB685190.1)

Given that the two sites had different sample sizes both for hosts and parasites (see results), and in order to assess haemosporidian species richness and to compare values of this parameter at the two sampling sites, we performed a rarefaction analysis (Gotelli and Colwell 2001). For rarefaction we used the package 'vegan' (Oksanen et al. 2013) in R (R Development Core Team 2011). Rarefaction calculates the expected number of species in a random subsample of individuals from a single, large collection (Gotelli and Colwell 2001). Rarefaction curves were then built using subsample size on the $x$ axis and expected number of species in the $y$ axis using custom $\mathrm{R}$ scripts (obtained from http://www. jennajacobs.org/R/rarefaction.html). To test for possible specialist parasite-host associations we used the hypergeometric distribution function in $\mathrm{R}$ ( $\mathrm{R}$ Development Core Team 2011) to calculate the probability of drawing the number of individuals of a parasite species (the observed number of such species) from the pool of individuals (all individuals of all bird species) and finding the same parasite species.

\section{RESULTS}

A total of 53 birds from 25 species were sampled with 1-7 individuals per species (mean $\pm \mathrm{SD}=2.12 \pm 1.51$ ); 14 of these birds ( 11 species) were caught at $1640 \mathrm{~m}$ asl and 39 (18 species) at $2100 \mathrm{~m}$ asl, (Table 1$)$. Seventeen birds (32.1\%) belonging to 11 species were identified as infected by at least 1 genus of avian haemosporidian. Among these, the most common genus was Leucocytozoon (detected in $58.8 \%$ of individuals belonging to 9 bird species), followed by Haemoproteus in $41.2 \%$ (belonging to 3 species), Plasmodium in $23.5 \%$ (belonging to 4 bird species) and Parahaemoproteus in $5.9 \%$ (only 1 individual infected). Five individuals $(9.4 \%)$ presented infections by 2 genera. At an altitude of $1640 \mathrm{~m}$ asl $57.1 \%$ of birds captured were infected by at least 1 genus of haemosporidian, compared to a $23.7 \%$ of infected birds at $2100 \mathrm{~m}$ asl. The most common genus of haemosporidian found at $1640 \mathrm{~m}$ asl was Leucocytozoon (45.4\%), followed by Plasmodium (27.3\%), Haemoproteus (18.2\%), and subgenus Parahaemoproteus $(9.1 \%)$. Double infections were found in $27.3 \%$ of birds caught at $1640 \mathrm{~m}$ asl. At an altitude of $2100 \mathrm{~m}$ asl Haemoproteus and Leucocytozoon accounted for $45.4 \%$ of infections each and Plasmodium was found in only 1 individual (9.1\%). Double infections were found in $18.2 \%$ of individuals at $2100 \mathrm{~m}$ asl. 
Table 1. Bird species captured at two elevation points in the Sierra Nevada de Santa Marta and occurrence of haemosporidians of the genera Plasmodium, Leucocytozoon, and Haemoproteus, and subgenus Parahaemoproteus. Number of birds infected by each haemosporidian genera (or subgenus) for each species is shown.

\begin{tabular}{|c|c|c|c|c|c|c|c|}
\hline Family & Species name & $\mathrm{N}$ & Altitude $(\mathrm{N})$ & N Plasmodium & $\mathrm{N}$ Leucocytozoon & $\mathrm{N}$ Haemoproteus & N Parahaemoproteus \\
\hline \multirow{3}{*}{ Trochilidae } & Amazilia saucerrotti & 1 & 2100 & & & & \\
\hline & Colibri thalassinus & 1 & 2100 & & & & \\
\hline & Metallura tyrianthina & 1 & 2100 & & & 1 & \\
\hline Ramphastidae & Aulacorhynchus prasinus & 1 & 2100 & & & & \\
\hline \multirow[t]{4}{*}{ Furnariidae } & Anabacerthia striaticollis & 2 & 2100 & & 1 & & \\
\hline & Automolus rubiginosus & 1 & 1640 & & & & \\
\hline & Lepidocolaptes lacrymiger & 3 & $1640(1)$ & & & & \\
\hline & & & $2100(2)$ & & & & \\
\hline \multirow[t]{7}{*}{ Tyrannidae } & Elaenia flavogaster & 3 & 2100 & & & & \\
\hline & Elaenia frantzi & 2 & 2100 & & & & \\
\hline & Mionectes olivaceus & 3 & $1640(1)$ & & & & \\
\hline & & & $2100(2)$ & & 1 & & \\
\hline & Myiodynastes maculatus & 1 & 1640 & & & & \\
\hline & Ochtoeca diadema & 1 & 2100 & & & & \\
\hline & Pyrrhomyias cinnamomeus & 1 & 1640 & & & & \\
\hline Vireonidae & Vireo leucophrys & 1 & 1640 & & & & 1 \\
\hline \multirow[t]{2}{*}{ Trogloditidae } & Henicorhina leucophrys & 4 & $1640(2)$ & & & & \\
\hline & & & $2100(2)$ & & & & \\
\hline \multirow[t]{2}{*}{ Turdidae } & Turdus flavipes & 2 & 1640 & 1 & 1 & & \\
\hline & Turdus olivater & 1 & 1640 & 1 & & & \\
\hline \multirow[t]{4}{*}{ Parulidae } & Basileuterus culicivorus & 1 & 2100 & & & & \\
\hline & Myioborus flavivertex ${ }^{\dagger}$ & 5 & 2100 & & 1 & & \\
\hline & Myiothlypis conspicillata & 1 & 2100 & & & & \\
\hline & Vermivora peregrina $a^{\ddagger}$ & 2 & 2100 & & & 1 & \\
\hline \multirow[t]{3}{*}{ Emberizidae } & Atlapetes melanocephalus ${ }^{\dagger}$ & 7 & $1640(2)$ & & 1 & 2 & \\
\hline & & & $2100(5)$ & & 1 & 3 & \\
\hline & Arremon basilicus $^{\dagger}$ & 2 & 1640 & 1 & 2 & & \\
\hline \multirow[t]{2}{*}{ Thraupidae } & Diglossa albilatera & 3 & 2100 & & & & \\
\hline & Diglossa humeralis & 3 & 2100 & 1 & 1 & & \\
\hline Total & 25 & 53 & & 4 & 9 & 7 & 1 \\
\hline $\begin{array}{l}\text { Endemic } \\
\text { Migratory }\end{array}$ & & & & & & & \\
\hline
\end{tabular}

\section{Prevalence of avian haemosporidians in endemic species}

Within the bird species we captured, 3 were endemic to the SNSM: Santa Marta Brush Finch, Atlapetes melanocephalus (7 individuals); Yellow-crowned Redstart, Myioborus flavivertex (4 individuals) and Colombian Brush Finch, Arremon basilicus (2 individuals). Of the individuals from endemic species $61.5 \%$ were infected with avian haemosporidians compared to a $22.5 \%$ of nonendemics (Table 1). Both individuals of the species Arremon basilicus were infected by the genus Leucocytozoon. Atlapetes melanocephalus had a haemosporidian prevalence of $71.4 \%$; Haemoproteus sp. accounted for $100 \%$ of these infections, while Leucocytozoon was found in $40 \%$ of infected birds ( 2 individuals presented infections by both genera). One individual of Myioborus flavivertex was infected with Leucocytozoon sp. $(25 \%$ prevalence).

\section{Species of haemosporidians}

Sequencing of the 22 PCR products that were positive for haemosporidian infection revealed a total of 12 unique sequences that grouped into 9 lineages (Table 2, Figure 2). All sequences identified had a sequence identity of at least $99 \%$ to sequences reported in GenBank (Table 2), 7 of these had not been previously reported and have been deposited in GenBank (accession numbers KX130084-KX130090). Four lineages had 100\% match to sequences previously reported in the Neotropics including: Haemoproteus witti PA182, Leucocytozoon lutzi PA286, Plasmodium sp. HMA2012, and Leucocytozoon sp. LT-011 (Table 2). One lineage had $100 \%$ match to Plasmodium sp. POMFER01, a lineage that has previously been reported in China (Table 2). The phylogenetic analysis of the identified sequences revealed 2 lineages of Haemoproteus, 1 of Parahaemoproteus, 3 of Plasmodium, and 3 of Leucozytozoon (Fig. 2). The tree had wellsupported nodes, except for the node separating Leucocytozoon lineages ChL11 and L-T011 (Fig. 2). The most abundant lineage identified was $99 \%$ identical ( 1 or 2 bp different) to the previously described Haemoproteus lineage DICER01 (González et al. 2015), accounting for $22.7 \%$ of infections, all of which were found in the same host species, the SNSM endemic A. melanocephalus. The probability of finding the DICER01-similar lineage always infecting $A$. melanocephalus just by chance was 0.0082 ; thus, it is likely that there is a specialist association between the DICER01similar lineage and the bird species $A$. melanocephalus. The other lineages that were detected in more than 1 individual were present in several host species (Table 2, Fig. 2). 
Table 2. Avian haemosporidian lineages detected in this study and their sequence identity to previously detected lineages published in GenBank. Host species where lineages have been detected (in this study and previous ones) are listed.

\begin{tabular}{|c|c|c|c|c|c|c|}
\hline Genus & $\begin{array}{l}\text { closest GenBank } \\
\text { match (sequence } \\
\text { identity) }\end{array}$ & $\begin{array}{l}\text { Reference (closest } \\
\text { GenBank match) }\end{array}$ & $\begin{array}{l}\text { GenBank } \\
\# \\
\text { (Closest } \\
\text { match) }\end{array}$ & $\begin{array}{l}\text { Host species } \\
\text { (this study) }\end{array}$ & $\begin{array}{l}\text { Host species (previous } \\
\text { studies) }\end{array}$ & $\begin{array}{l}\text { Locality (previous } \\
\text { studies) }\end{array}$ \\
\hline Haemoproteus & $\begin{array}{l}\text { H. witti PA182 } \\
(100 \%)\end{array}$ & $\begin{array}{l}\text { González et al. } \\
2015\end{array}$ & KC121053.1 & $\begin{array}{l}\text { Metallura tyrianthina, } \\
\text { Vermivora peregrina }\end{array}$ & $\begin{array}{l}\text { Eriocnemis vestitus, } \\
\text { Eriocnemis cupreoventris, } \\
\text { Eriocnemis derbyi, } \\
\text { Eriocnemis vestita }\end{array}$ & $\begin{array}{l}\text { Colombia Andes, } \\
\text { Perú }\end{array}$ \\
\hline Haemoproteus & $\begin{array}{l}\text { sp. DICER-01 } \\
(99 \%)\end{array}$ & $\begin{array}{l}\text { González et al. } \\
2015\end{array}$ & $\begin{array}{l}\text { KM2113- } \\
49.2\end{array}$ & Atlapetes melanocephalus & $\begin{array}{l}\text { Buhtraupis montana, } \\
\text { Diglossa caerulescens }\end{array}$ & Colombia, Galápagos \\
\hline Leucocytozoon & sp. ChL11 $(99 \%)$ & $\begin{array}{l}\text { Martínez et al., } \\
\text { unpublished } \\
\text { manuscript }\end{array}$ & EF153665.1 & $\begin{array}{l}\text { Mionectes olivaceus, } \\
\text { Anabacerthia striaticollis }\end{array}$ & Zonotrichia capensis & Chile \\
\hline Leucocytozoon & sp. L-T011 (100\%) & $\begin{array}{l}\text { C. C. Witt and S. } \\
\text { M. McNew, } \\
\text { unpublished } \\
\text { manuscript }\end{array}$ & JQ988120.1 & $\begin{array}{l}\text { Diglossa humeralis, } \\
\text { Atlapetes melanocephalus, } \\
\text { Arremon basilicus }\end{array}$ & Diglossa humeralis & Perú \\
\hline Leucocytozoon & sp. SPOW6 $(99 \%)$ & Ishak et al. 2008 & EU627802.1 & $\begin{array}{l}\text { Vireo leucophrys, Turdus } \\
\text { flavipes, Myioborus } \\
\text { flavivertex }\end{array}$ & $\begin{array}{l}\text { Strix occidentalis } \\
\text { occidentalis }\end{array}$ & USA, California \\
\hline Parahaemoproteus & P. vireonis $(99 \%)$ & $\begin{array}{l}\text { González et al. } \\
2015\end{array}$ & KF537331.1 & Vireo leucophrys & Vireo olivaceus & Colombia, Perú \\
\hline Plasmodium & $\begin{array}{l}\text { P. lutzi PA286 } \\
(100 \%)\end{array}$ & $\begin{array}{l}\text { González et al. } \\
2015\end{array}$ & KJ780795.1 & Diglossa humeralis & Diglossa cyanea & Colombia Andes \\
\hline Plasmodium & $\begin{array}{l}\text { sp. HMA-2012 } \\
(99-100 \%)\end{array}$ & $\begin{array}{l}\text { Archer et al., } \\
\text { unpublished } \\
\text { manuscript }\end{array}$ & JN819328.1 & $\begin{array}{l}\text { Turdus flavipes, Turdus } \\
\text { olivater }\end{array}$ & $\begin{array}{l}\text { Tangara icterocephala, } \\
\text { Turdus asimilis }\end{array}$ & Costa Rica \\
\hline Plasmodium & $\begin{array}{l}\text { sp. POMFER01 } \\
(100 \%)\end{array}$ & Zhang et al. 2014 & KJ145051.1 & Arremon basilicus & Ficedula monileger & China \\
\hline
\end{tabular}

${ }^{\dagger}$ Martínez, J., S. Merino, J. Moreno, R. Vasquez, I. Sanchez-Monsalvez, C. F. Estades, S. Ippi, P. Sabat, R. Rozzi, S. McGehee, M. A. RodriguezGirones, J. Martinez-de la Puente, S. Garcia-Fraile, and E. Lobato.

${ }^{\ddagger}$ Archer, H. M., C. D. Mendenhall, C. H. Sekercioglu, and R. N. M. Sehgal.

In most cases where several hosts presented infections with the same haemosporidian lineage, these were found at both altitudes (Fig. 2). The exception was one lineage (Haemoproteus witti PA182; González et al. 2015), which was detected in only 2 individuals of different species at $2100 \mathrm{~m}$ asl.

Rarefaction curves clearly show that haemosporidian species richness is higher at low altitudes after correcting for difference in sample size between the two sampling areas (Appendix 1). At a subsample size of 9 (the minimum number of single haemosporidians observed at a specific site) rarefaction gave a species richness of $6.45,5.58$, and 8.20 for all samples, only samples from $2100 \mathrm{~m}$ asl and only samples from $1640 \mathrm{~m}$ asl, respectively. The slopes of the rarefaction curves also suggest that the actual number of haemosporidian lineages is likely to be much higher than the observed value and sampling effort needs to be more intense to identify all species/lineages of haemosporidians present in the area.

\section{DISCUSSION}

In this study we assessed infection by haemosporidians in birds from the Sierra Nevada de Santa Marta (SNSM), an important endemic bird area, and report a possible new parasite-host association. We also found that the three endemic species we sampled were infected by at least one genus of haemosporidian with a high prevalence. Our results clearly show that the actual number of haemosporidian lineages in this area is likely to be much larger than the numbers we found, and considering the conservation concern of the SNSM and its endemic species, the ecology of these parasite - host associations needs to be further explored.

All three genera (and one subgenus) of haemosporidians were represented in our sample of 53 birds. We found an overall prevalence of haemosporidians of $32.1 \%$. This result concurs with prevalence reported for the Neotropics (Latta and Ricklefs 2010, Ricklefs et al. 2011, Lacorte et al. 2013, Marzal et al. 2015). In contrast, a previous large-scale study (1487 birds screened) across Neotropical highlands in Colombia (González et al. 2015) found an overall prevalence of $10 \%$, although this study did not screen for Leucocytozoon infections and this genus was the most common in our study (see below). However, the prevalence in our study was similar to that reported in another small-scale study in the Chingaza Park, Colombia at elevations above $3000 \mathrm{~m}$ asl, which included Leucocytozoon in the screening, and reported an overall haemosporidian prevalence of $27.9 \%$ (Rodríguez et al. 2009). Furthermore, the most common haemosporidian genus found in the cited study was Leucocytozoon with a prevalence of $21.3 \%$ (Rodríguez et al. 2009). This result is similar to ours where the most common haemosporidian genus was also Leucocytozoon with an overall prevalence of $17 \%$, and contrasts with previous reports in the Neotropics, where prevalence for this genus has 
Fig. 2. Phylogenetic tree of cytochrome b sequences of haemoporidians detected in birds sampled in the Sierra Nevada de Santa Marta at two different altitudes (1640 and $2100 \mathrm{~m}$ asl). Each line is composed of the host species name of each sample (in smaller case), followed by the altitude were the individual was caught and the name of the closest haemosporidian lineage, as shown in Table 2, in larger font. Vertical dashed lines span individuals infected with each haemosporidian lineage. Bootstrap values are displayed at each node. The tree was rooted with a cytochrome b sequence from Babesia gibsoni.

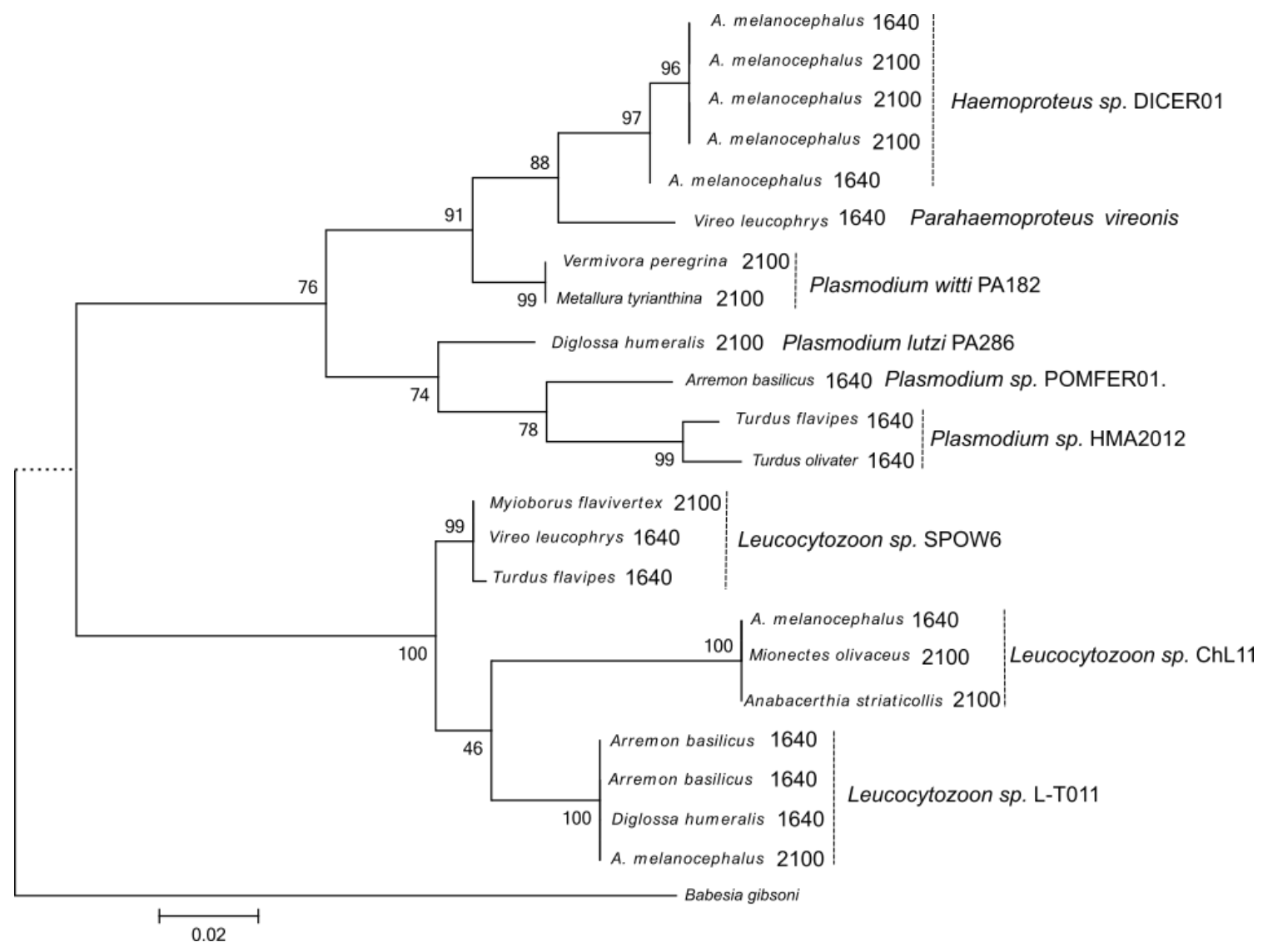

been as low as $0.2 \%$ (White et al. 1978), $0.3 \%$ (Basto et al. 2006), $2 \%$ (Valkiūnas et al. 2003) or completely absent (Rodríguez and Matta 2001). This is probably a reflection of the ecological constraints of Leucocytozoon, which is transmitted by blackflies (Fallis et al. 1951). The larvae of these vectors require streams with constant current rates (Zahar 1951), which are common in mountainous areas such as the SNSM.

Our haemosporidian cytochrome b phylogeny revealed a total of nine unique lineages with well-supported nodes, except for the node separating Leucocytozoon lineages ChL11 and L-T011 (Fig. 2). To separate these two lineages we would probably need to include additional molecular markers or to increase the size of the cytochrome $b$ fragment sequenced. Given the small sample size of the birds screened in the present study, the number of lineages found is a considerable value and is comparable with other studies in the Neotropics that have found a large number of lineages (Fallon et al. 2005, Lacorte et al. 2013, Clark et al. 2014). The high species richness we report agrees with the hypothesis that haemosporidian diversity may be a function of avian and/or vector host diversity, both of which are high in tropical continental regions (reviewed in Clark et al. 2014). Given the high bird species diversity of the SNSM, the number of avian haemosporidian species in this Neotropical region could be considerably high. In fact, the rarefaction curve built with our haemosporidian species presence data shows that the actual species richness is likely to be much higher than the one we observed. Host switching has been shown to be a key factor in haemosporidian speciation (Ricklefs et al. 2014) and the high bird species richness in the SNSM could accelerate this process because more hosts are available and host switching would be more likely to occur. A more exhaustive screening of haemosporidian parasites in the avifauna of the SNSM is required to confirm this.

Apart from diversification by host switching, another possibility for the high haemosporidian diversity found in the SNSM is that parasites could have been introduced by non-native birds that migrate through the area. Invasion of haemosporidians has previously been reported for highly generalist species, such as Plasmodium relictum (Marzal et al. 2015). The lineages detected in this study are found in several host species, and they have been reported elsewhere suggesting that they could have been 
introduced easily from migrating bird species. In this study we only captured two individuals of the migrating species Vermivora peregrina, resident of North America, one of which was infected with the previously reported Haemoproteus witti lineage PA182 (González et al. 2015). The same PA182 sequence was detected in Metallura tyrianthina in our study, a species of hummingbird that is widespread across northern South America (del Hoyo et al. 1999). Distribution of both species during the wintering period for $V$. peregrina overlaps over a large area, therefore we cannot make any assumptions about the transmission of this parasite lineage between the two species or about the direction of transmission. A more comprehensive screening including more individuals and more species would be needed to confirm this.

Avian haemosporidians could potentially affect the distribution of host species if the pathogens decrease the fitness of hosts (Warner 1968, Lachish et al. 2011a). This effect could be more drastic in endemic species that have restricted distributions and cannot, therefore, disperse to disease free areas. Although our sample size is not large enough to make statistical comparisons between the levels of infection between endemic and nonendemic birds, our result of higher prevalence in endemic birds concur with those of a previous community-level study that found higher prevalence of avian haemosporidians in endemic species than in nonendemics in the Dominican Republic (Latta and Ricklefs 2010). This finding has important implications for the conservation of the endemic species in the SNSM and poses the question whether this phenomenon is widespread among the SNSM endemic bird species and other areas and altitudes of the SNSM. Greater sampling effort across a larger altitudinal range in this and other areas of the SNSM is needed.

Host specificity is key in the biology of parasites. Host specialization might increase the risk of extinction for the parasite, but allows increased contact among individuals of a parasite species that is restricted to a few species, since parasite transmission between host congeners is more likely (Beadell et al. 2009). Long-term localized associations of a vertebrate host and a parasite may result in coevolution and a subsequent specialist association as has been previously suggested in an avian haemosporidian system where specialist haemosporidians were restricted to resident and endemic avian hosts (Latta and Ricklefs 2010). In line with this, the most common lineage detected in our study (Haemoproteus DICER01-closely related lineage) was only detected in one species, the SNSM endemic Atlapetes melanocephalus, thus, this could represent a host specialization strategy of this lineage. This observation is consistent with the hypothesis that lineages of Haemoproteus are more constrained at the level of host species than other haemosporidian genera (Fallon et al. 2005, Beadell et al. 2009), and might suggest a longterm localized coevolution of a parasite-host relationship, which is more likely to occur in endemic host species. However, to confirm unequivocally the existence of a specialist association it is necessary to screen blood smears to determine whether the infections are viable and to screen a larger number of host species to confirm that no other host species is infected with this lineage. The lineage DICER01 has been reported in Buthraupis montana and Diglossa caerulescens (González et al. 2015). Nonetheless, it is difficult to know whether our DICER01-closely related lineage corresponds to a new species or it in fact represents intraspecific genetic diversity of DICER01 that had not previously been reported. Sequencing longer cytochrome $b$ fragments of the mitochondrial genomes of both the original DICER01 lineage and the one detected in this study would be needed to clarify this.

Avian haemosporidian transmission is affected by the environmental variation at different scales, both in space (Wood et al. 2007, Lachish et al. 2011b) and time (Fallon et al. 2004, Lalubin et al. 2013). We detected a lower prevalence at high altitudes despite having screened a larger bird sample at $2100 \mathrm{~m}$ asl. This is in agreement with evidence of the effects of temperature and altitude on the abundance and activity patterns of vectors (Ahumada et al. 2004, Gilioli and Mariani 2011, Zamora-Vilchis et al. 2012) and on the development of haemosporidian parasites (Valkiūnas 2004, LaPointe et al. 2010). Further sampling is needed across a larger elevation gradient to further support our findings. We did not measure other environmental variables that could potentially affect the prevalence of haemosporidians in this area. The SNSM possesses a large variety of biomes and habitats, hence providing a great opportunity for assessment of environmental variables that could affect the distribution of the different haemosporidian lineages. Future work should focus on sampling hosts in areas with different environmental conditions in the SNSM.

Our data revealed high prevalence of avian haemosporidians in all captured endemic bird species in the SNSM during our study. Given that the Sierra Nevada in Northern Colombia is considered a center of endemism (Cracraft 1985, Carbono and LozanoContreras 1997), high prevalence and diversity of haemosporidians suggests a threat for wildlife. Global changes such as alterations in landscape and habitat, and climate change-induced shifts in wildlife populations have important implications in disease ecology (Deem et al. 2001). In the SNSM human settlement, the advancing agricultural and cattle ranching frontier, and the cultivation of illegal crops have led to loss of more than $70 \%$ of the original forest cover (Álvarez 2002). The landscape change combined with disease threat could have adverse consequences for the persistence of wild bird populations (Sehgal 2010). Further work is urgently needed to assess whether haemosporidians represent a threat for the conservation of the local avifauna. More exhaustive sampling across a larger altitudinal range, including other types of habitats and different time periods is of utter importance to estimate the extent of the presence of the disease in this important endemic bird area and to further understand the evolutionary and ecological dynamics of the disease in areas of high host and parasite species richness. Once a comprehensive screening of haemosporidians in the wild avifauna is performed, further studies should focus on determining the factors that modulate infection and transmission in the area and assessing the effects of haemosporidian infection on various aspects of host fitness.

Responses to this article can be read online at: http://www.ace-eco.org/issues/responses.php/834

\section{Acknowledgments:}

We thank Kelly González, Dariel Martínez, and Andrea Morales for their help in the field and the Universidad de Antioquia for providing financial support. 


\section{LITERATURE CITED}

Ahumada, J. A., D. Lapointe, M. D. Samuel. 2004. Modeling the population dynamics of Culex quinquefasciatus (Diptera: Culicidae), along an elevational gradient in Hawaii. Journal of Medical Entomology 41:1157-1170. http://dx.doi. org/10.1603/0022-2585-41.6.1157

Álvarez, M. D. 2002. Illicit crops and bird conservation priorities in Colombia. Conservation Biology 16:1086-1096. http://dx.doi. org/10.1046/j.1523-1739.2002.00537.x

Arèvalo, E., S. K. Davis, and J. W. Sites Jr. 1994. Mitochondrial DNA sequence divergence and phylogenetic relationships among eight chromosome races of the Sceloporus grammicus complex (Phrynosomatidae) in Central Mexico. Systematic Biology 43:387-418. http://dx.doi.org/10.1093/sysbio/43.3.387

Asghar, M., D. Hasselquist, B. Hansson, P. Zehtindjiev, H. Westerdahl, and S. Bensch. 2015. Hidden costs of infection: chronic malaria accelerates telomere degradation and senescence in wild birds. Science 347:436-438. http://dx.doi.org/10.1126/ science. 1261121

Atkinson, C. T., R. J. Dusek, and J. K. Lease. 2001. Serological responses and immunity to superinfection with avian malaria in experimentally-infected Hawaii Amakihi. Journal of Wildlife Diseases 37:20-27. http://dx.doi.org/10.7589/0090-3558-37.1.20

Atkinson, C. T., R. J. Dusek, K. L. Woods, and W. M. Iko. 2000. Pathogenicity of avian malaria in experimentally-infected Hawaii Amakihi. Journal of Wildlife Diseases 36:197-204. http://dx.doi. org/10.7589/0090-3558-36.2.197

Basto, N., O. Rodríguez, and C. Marinkelle. 2006. Haematozoa in birds from La Macarena National Natural Park (Colombia). Caldasia 28:371-377.

Beadell, J. S., R. Covas, C. Gebhard, F. Ishtiaq, M. Melo, B. K. Schmidt, S. L. Perkins, G. R. Graves, and R. C. Fleischer. 2009. Host associations and evolutionary relationships of avian blood parasites from West Africa. International Journal for Parasitology 39:257-266. http://dx.doi.org/10.1016/j.ijpara.2008.06.005

Bensch, S., O. Hellgren, and J. Pérez-Tris. 2009. MalAvi: a public database of malaria parasites and related haemosporidians in avian hosts based on mitochondrial cytochrome b lineages. Molecular Ecology Resources 9:1353-1358. http://dx.doi. org/10.1111/j.1755-0998.2009.02692.x

Bensch, S., M. Stjernman, D. Hasselquist, Ö. Örjan, B. Hannson, H. Westerdahl, and R. T. Pinheiro. 2000. Host specificity in avian blood parasites: a study of Plasmodium and Haemoproteus mitochondrial DNA amplified from birds. Proceedings of the Royal Society of London. Series B: Biological Sciences 267:1583-1589. http://dx.doi.org/10.1098/rspb.2000.1181

Calero-Riestra, M., and J. T. García. 2016. Sex-dependent differences in avian malaria prevalence and consequences of infections on nestling growth and adult condition in the Tawny pipit, Anthus campestris. Malaria Journal 15:178. http://dx.doi. org/10.1186/s12936-016-1220-y

Carbono, E., and G. Lozano-Contreras. 1997. Endemismos y otras singularidades de la Sierra Nevada de Santa Marta, Colombia: posibles causas de origen y necesidad de conservarlos. Revista de la Academia Colombiana de Ciencias 21:409-419.
Cellier-Holzem, E., R. Esparza-Salas, S. Garnier, and G. Sorci. 2010. Effect of repeated exposure to Plasmodium relictum (lineage SGS1) on infection dynamics in domestic canaries. International Journal for Parasitology 40:1447-1453. http://dx.doi.org/10.1016/ j.ijpara.2010.04.014

Clark, N. J., S. M. Clegg, and M. R. Lima. 2014. A review of global diversity in avian haemosporidians (Plasmodium and Haemoproteus: Haemosporida): new insights from molecular data. International Journal for Parasitology 44:329-338. http://dx. doi.org/10.1016/j.ijpara.2014.01.004

Cracraft, J. 1985. Historical biogeography and patterns of differentiation within the South American avifauna: areas of endemism. Ornithological Monographs 36:49-84. http://dx.doi. org/10.2307/40168278

Daszak, P., A. A. Cunningham, and A. D. Hyatt. 2000. Emerging infectious diseases of wildlife--threats to biodiversity and human health. Science 287:443-449. http://dx.doi.org/10.1126/ science.287.5452.443

Deem, S. L., W. B. Karesh, and W. Weisman. 2001. Putting theory into practice: wildlife health in conservation. Conservation Biology 15:1224-1233. http://dx.doi.org/10.1111/j.1523-1739.2001.00336. $\mathrm{x}$

del Hoyo, J., A. Elliott, and J. Sargatal. 1999. Handbook of the birds of the world, Vol. 5. Barn-owls to Hummingbirds. Lynx Edicions, Barcelona, Spain.

Dobson, A., and J. Foufopoulos. 2001. Emerging infectious pathogens of wildlife. Philosophical Transactions of the Royal Society of London. Series B: Biological Sciences 356:1001-1012. http://dx.doi.org/10.1098/rstb.2001.0900

Fallis, A. M., D. M. Davies, and M. A. Vickers. 1951. Life history of Leucocytozoon simondi Mathis and Leger in natural and experimental infections and blood changes produced in the avian host. Canadian Journal of Zoology 29:305-328. http://dx.doi. org/10.1139/z51-028

Fallon, S. M., E. Bermingham, and R. E. Ricklefs. 2005. Host specialization and geographic localization of avian malaria parasites: a regional analysis in the Lesser Antilles. American Naturalist 165:466-480. http://dx.doi.org/10.1086/428430

Fallon, S. M., R. E. Ricklefs, S. C. Latta, and E. Bermingham. 2004. Temporal stability of insular avian malarial parasite communities. Proceedings of the Royal Society of London Series B-Biological Sciences 271:493-500. http://dx.doi.org/10.1098/ rspb.2003.2621

Freed, L. A., R. L. Cann, M. L. Goff, W. A. Kuntz, and G. R. Bodner. 2005. Increase in avian malaria at upper elevation in Hawaii. Condor 107:753-764. http://dx.doi.org/10.1650/7820.1

Garamszegi, L. Z. 2011. Climate change increases the risk of malaria in birds. Global Change Biology 17:1751-1759. http://dx. doi.org/10.1111/j.1365-2486.2010.02346.x

Gilioli, G., and L. Mariani. 2011. Sensitivity of Anopheles gambiae population dynamics to meteo-hydrological variability: a mechanistic approach. Malaria Journal 10:294. http://dx.doi. org/10.1186/1475-2875-10-294 
González, A., I. Lotta, L. F. García, L. I. Moncada, and N. E. Matta. 2015. Avian haemosporidians from Neotropical highlands: evidence from morphological and molecular data. Parasitology International 64:48-59. http://dx.doi.org/10.1016/j. parint.2015.01.007

Gotelli, N. J., and R. K. Colwell. 2001. Quantifying biodiversity: procedures and pitfalls in the measurement and comparison of species richness. Ecology letters 4:379-391. http://dx.doi. org/10.1046/j.1461-0248.2001.00230.x

Hall, T. A. 1999. BioEdit: a user friendly biological sequence alignment editor and analysis program for Windows 95/98/NT. Nucleic Acid Symposium Series 41:95-98.

Hatcher, M. J., J. T. A. Dick, and A. M. Dunn. 2012. Disease emergence and invasions. Functional Ecology 26:1275-1287. http://dx.doi.org/10.1111/j.1365-2435.2012.02031.x

Hellgren, O., J. Pérez-Tris, and S. Bensch. 2009. A jack-of-alltrades and still a master of some: prevalence and host range in avian malaria and related blood parasites. Ecology 90:2840-2849. http://dx.doi.org/10.1890/08-1059.1

Hellgren, O., J. Waldenström, and S. Bensch. 2004. A new PCR assay for simultaneous studies of Leucocytozoon, Plasmodium, and Haemoproteus from avian blood. Journal of Parasitology 90:797-802. http://dx.doi.org/10.1645/GE-184R1

Instituto Geográfico Agustín Codazzi (IGAC). 1993. Proyecto piloto de ordenamiento territorial de la Sierra Nevada de Santa Marta, una aproximación metodológica. IGAC, Bogotá, Colombia.

Ishak, H. D., J. P. Dumbacher, N. L. Anderson, J. J. Keane, G. Valkiūnas, S. M. Haig, L. A. Tell, and R. N. M. Sehgal. 2008. Blood parasites in owls with conservation implications for the spotted owl (Strix occidentalis). PLoS ONE 3:e2304. http://dx. doi.org/10.1371/journal.pone.0002304

Lachish, S., S. C. L. Knowles, R. Alves, M. J. Wood, and B. C. Sheldon. 2011a. Fitness effects of endemic malaria infections in a wild bird population: the importance of ecological structure. Journal of Animal Ecology 80:1196-1206. http://dx.doi. org/10.1111/j.1365-2656.2011.01836.x

Lachish, S., S. C. L. Knowles, R. Alves, M. J. Wood, and B. C. Sheldon. 2011 b. Infection dynamics of endemic malaria in a wild bird population: parasite species-dependent drivers of spatial and temporal variation in transmission rates. Journal of Animal Ecology 80:1207-1216. http://dx.doi.org/10.1111/j.1365-2656.2011.01893. $\mathrm{x}$

Lacorte, G. A., G. M. F. Félix, R. R. B. Pinheiro, A. V Chaves, G. Almeida-Neto, F. S. Neves, L. O. Leite, F. R. Santos, and É. M. Braga. 2013. Exploring the diversity and distribution of Neotropical avian malaria parasites: a molecular survey from Southeast Brazil. PLoS ONE 8:e57770. http://dx.doi. org/10.1371/journal.pone.0057770

Lalubin, F., A. Delédevant, O. Glaizot, and P. Christe. 2013. Temporal changes in mosquito abundance (Culex pipiens), avian malaria prevalence and lineage composition. Parasites \& Vectors 6:307. http://dx.doi.org/10.1186/1756-3305-6-307
LaPointe, D. A., C. T. Atkinson, and M. D. Samuel. 2012. Ecology and conservation biology of avian malaria. Annals of the New York Academy of Sciences 1249:211-226. http://dx.doi. org/10.1111/j.1749-6632.2011.06431.x

LaPointe, D. A., M. L. Goff, and C. T. Atkinson. 2010. Thermal constraints to the sporogonic development and altitudinal distribution of avian malaria Plasmodium relictum in Hawaii. Journal of Parasitology 96:318-324. http://dx.doi.org/10.1645/ GE-2290.1

Latta, S. C., and R. E. Ricklefs. 2010. Prevalence patterns of avian haemosporida on Hispaniola. Journal of Avian Biology 41:25-33. http://dx.doi.org/10.1111/j.1600-048X.2009.04685.x

Marzal, A., F. de Lope, C. Navarro, and A. P. Møller. 2005. Malarial parasites decrease reproductive success: an experimental study in a passerine bird. Oecologia 142:541-545. http://dx.doi. org/10.1007/s00442-004-1757-2

Marzal, A., L. García-Longoria, J. M. C. Callirgos, and R. N. M. Sehgal. 2015. Invasive avian malaria as an emerging parasitic disease in native birds of Peru. Biological Invasions 17:39-45. http://dx.doi.org/10.1007/s10530-014-0718-x

McGuire, J. A., C. C. Witt, D. L. Altshuler, and J. V. Remsen. 2007. Phylogenetic systematics and biogeography of hummingbirds: Bayesian and maximum likelihood analyses of partitioned data and selection of an appropriate partitioning strategy. Systematic Biology 56:837-856. http://dx.doi.org/10.1080/10635150701656360

Merino, S., J. Moreno, J. J. Sanz, and E. Arriero. 2000. Are avian blood parasites pathogenic in the wild? A medication experiment in Blue Tits (Parus caeruleus). Proceedings of the Royal Society B-Biological Sciences 267:2507-2510. http://dx.doi.org/10.1098/ rspb. 2000.1312

Møller, A. P., and J. T. Nielsen. 2007. Malaria and risk of predation: a comparative study of birds. Ecology 88:871-881. http://dx.doi.org/10.1890/06-0747

Oksanen, J., G. Blanchet, R. Kindt, P. Legendre, P. R. Minchin, R. B. O'Hara, G. L. Simpson, P. Solymos, M. H. H. Stevens, and H. Wagner. 2013. Vegan: Community Ecology Package. R package version 2.0-10. R Foundation for Statistical Computing, Vienna, Austria. [online.] URL: http://cran.r-project.org/package=vegan

R Development Core Team. 2011. R: A language and environment for statistical computing. $\mathrm{R}$ Foundation for Statistical Computing, Vienna, Austria. [online.] URL: http:// www.r-project.org

Richardson, D. S., F. L. Jury, K. Blaakmeer, J. Komdeur, and T. Burke. 2001. Parentage assignment and extra-group paternity in a cooperative breeder: the Seychelles warbler (Acrocephalus sechellensis). Molecular Ecology 10:2263-2273. http://dx.doi. org/10.1046/j.0962-1083.2001.01355.x

Ricklefs, R. E., S. M. Fallon, and E. Bermingham. 2004. Evolutionary relationships, cospeciation, and host switching in avian malaria parasites. Systematic Biology 53:111-119. http://dx. doi.org/10.1080/10635150490264987

Ricklefs, R., J. D. Gray, S. C. Latta, and M. Svensson-Coelho. 2011. Distribution anomalies in avian haemosporidian parasites 
in the southern Lesser Antilles. Journal of Avian Biology 42:570-584. http://dx.doi.org/10.1111/j.1600-048X.2011.05404. $\mathrm{x}$

Ricklefs, R. E., D. C. Outlaw, M. Svensson-Coelho, M. C. I. Medeiros, V. A. Ellis, and S. Latta. 2014. Species formation by host shifting in avian malaria parasites. Proceedings of the National Academy of Sciences of the United States of America 111:14816-14821. http://dx.doi.org/10.1073/pnas.1416356111

Rodríguez, O. A., and N. E. Matta. 2001. Blood parasites in some birds from eastern plains of Colombia. Memorias Do Instituto Oswaldo Cruz 96:1173-1176. http://dx.doi.org/10.1590/ S0074-02762001000800026

Rodríguez, O. A., H. Moya, and N. E. Matta. 2009. Avian blood parasites in the National Natural Park Chingaza: high Andes of Colombia. El Hornero 24:1-6.

Scott, M. E. 1988. The impact of infection and disease on animal populations: implications for conservation biology. Conservation Biology 2:40-56. http://dx.doi.org/10.1111/j.1523-1739.1988. tb00334.x

Sehgal, R. N. M. 2010. Deforestation and avian infectious diseases. Journal of Experimental Biology 213:955-960. http://dx. doi.org/10.1242/jeb.037663

Sehgal, R. N. M. 2015. Manifold habitat effects on the prevalence and diversity of avian blood parasites. International Journal for Parasitology: Parasites and Wildlife 4:421-430. http://dx.doi. org/10.1016/j.ijppaw.2015.09.001

Seutin, G., B. N. White, and P. T. Boag. 1991. Preservation of avian blood and tissue samples for DNA analyses. Canadian Journal of Zoology 69:82-90. http://dx.doi.org/10.1139/z91-013

Sol, D., R. Jovani, and J. Torres. 2003. Parasite mediated mortality and host immune response explain age-related differences in blood parasitism in birds. Oecologia 135:542-547. http://dx.doi. org/10.1007/s00442-003-1223-6

Stattersfield, A., M. Crosby, A. Long, and D. Wege. 1998. Endemic bird areas of the world: priorities for biodiversity conservation. Birdlife International, Cambridge, UK.

Strewe, R., and C. Navarro. 2004. New and noteworthy records of birds from the Sierra Nevada de Santa Marta region, northeastern Colombia. Bulletin of the British Ornithologists' Club 124:38-51.

Tamura, K., G. Stecher, D. Peterson, A. Filipski, and S. Kumar. 2013. MEGA6: Molecular Evolutionary Genetics Analysis version 6.0. Molecular Biology and Evolution 30:2725-2729. http:// dx.doi.org/10.1093/molbev/mst197

Thompson, R. C. A., A. J. Lymbery, and A. Smith. 2010. Parasites, emerging disease and wildlife conservation. International Journal for Parasitology 40:1163-1170. http://dx.doi.org/10.1016/j. ijpara.2010.04.009
Valkiūnas, G. 2004. Avian malaria parasites and other haemosporidia. CRC Press, Boca Raton, Florida, USA. http://dx. doi.org/10.1201/9780203643792

Valkiūnas, G., P. Salaman, and T. A. Iezhova. 2003. Paucity of hematozoa in Colombian birds. Journal of Wildlife Diseases 39:445-448. http://dx.doi.org/10.7589/0090-3558-39.2.445

van Riper III, C., C. Atkinson, and T. Seed. 1994. Plasmodia of birds. Pages 73-140 in J. P. Kreier, editor. Parasitic protozoa. Academic, New York, New York, USA.

van Riper III, C., S. G. Van Riper, M. L. Goff, and M. Laird. 1986. The epizootiology and ecological significance of malaria in Hawaiian land birds. Ecological Monographs 56:327-344. http:// dx.doi.org/10.2307/1942550

Waldenström, J., S. Bensch, D. Hasselquist, and Ö. Östman. 2004. A new nested polymerase chain reaction method very efficient in detecting Plasmodium and Haemoproteus infections from avian blood. Journal of Parasitology 90:191-194. http://dx.doi. org/10.1645/GE-3221RN

Warner, R. E. 1968. The role of introduced diseases in the extinction of the endemic Hawaiian avifauna. Condor 70:101-120. http://dx.doi.org/10.2307/1365954

White, E., E. Greiner, G. F. Bennett, and C. M. Herman. 1978. Distribution of the hematozoa of Neotropical birds. Revista de Biologia Tropical 26:43-102.

Wood, M. J., C. L. Cosgrove, T. A. Wilkin, S. C. L. Knowles, K. P. Day, and B. C. Sheldon. 2007. Within-population variation in prevalence and lineage distribution of avian malaria in Blue Tits, Cyanistes caeruleus. Molecular Ecology 16:3263-3273. http://dx. doi.org/10.1111/j.1365-294X.2007.03362.x

Zahar, A. 1951. The ecology and distribution of black-flies (Simuliidae) in south-east Scotland. Journal of Animal Ecology 20:33-62. http://dx.doi.org/10.2307/1643

Zamora-Vilchis, I., S. E. Williams, and C. N. Johnson. 2012. Environmental temperature affects prevalence of blood parasites of birds on an elevation gradient: implications for disease in a warming climate. PLOS ONE 7:e39208. http://dx.doi. org/10.1371/journal.pone.0039208

Zhang, Y., Y. Wu, Q. Zhang, D. Su, and F. Zou. 2014. Prevalence patterns of avian Plasmodium and Haemoproteus parasites and the influence of host relative abundance in Southern China. PLoS ONE 9:e99501. http://dx.doi.org/10.1371/journal.pone.0099501
Editor-in-Chief: Keith A.Hobson

Subject Editor: Dave Shutler
Sponsored by the Society of Canadian Ornithologists and Bird Studies Canada Parrainée par la Société des ornithologistes du Canada et Etudes d'oiseaux Canada

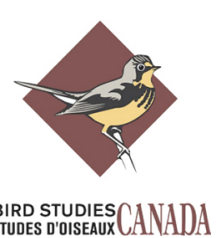


Appendix 1 Rarefacion curves of malaria species richness at $2100 \mathrm{~m}$ asl (high), $1640 \mathrm{~m}$ asl (low), or pooling samples at both locations (all). Each subsample was iterated as many times as possible given the number of samples in each subsample. Bars denote standard error of the iterations at each subsample.

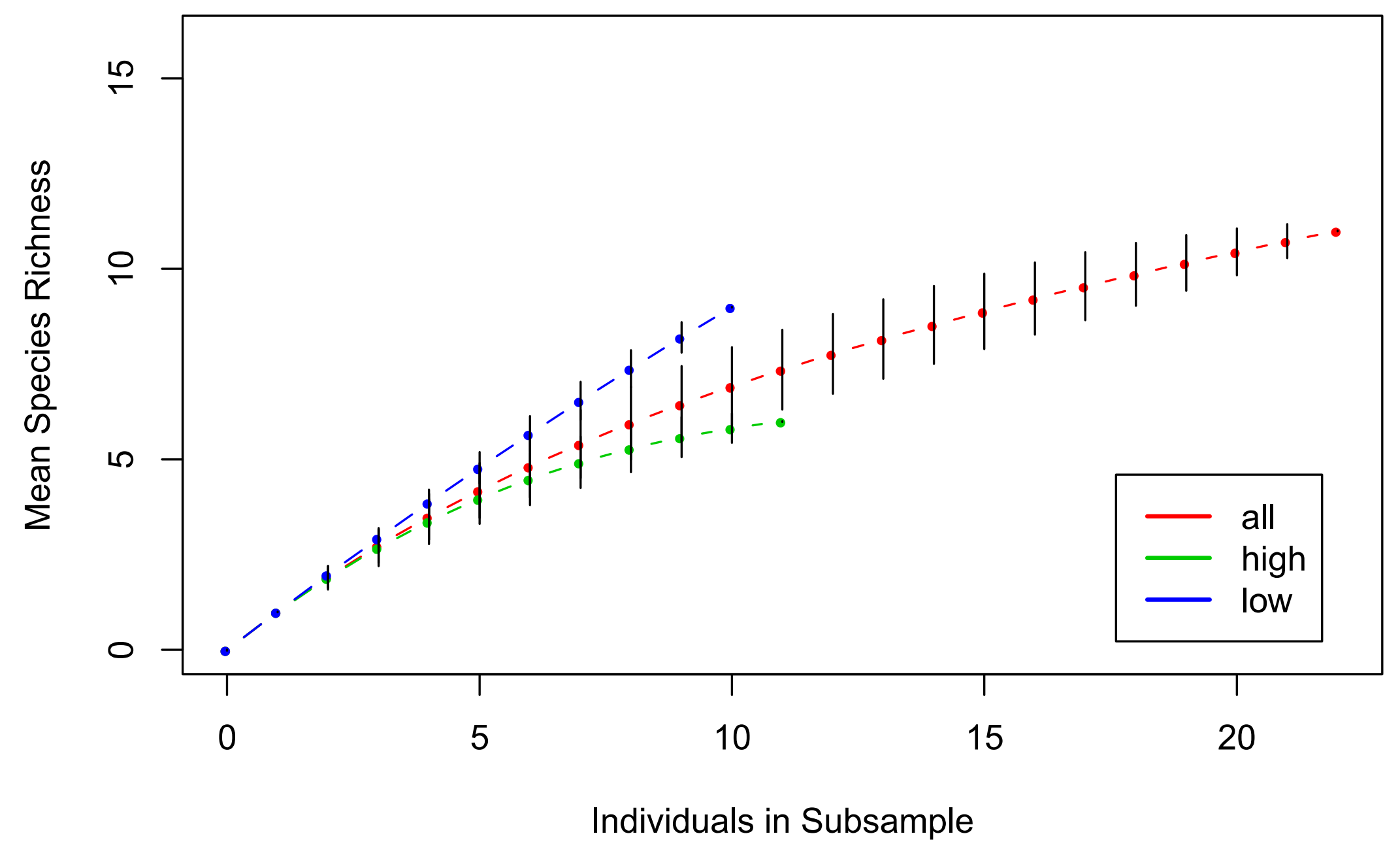

